\title{
Nilai-Nilai Pendidikan Dalam Tradisi Tingkeban Budaya Masyarakat Suku Jawa Ditinjau Dari Perspektif Filosofis
}

\section{Weni Sarbaini \\ Universitas Negeri Medan}

Corresponding Author: $\otimes$ sarbainiweni@gmail.com

\begin{tabular}{ll}
\hline & \multicolumn{1}{c}{ ABSTRACT } \\
\cline { 2 - 3 } & $\begin{array}{l}\text { Penelitian ini bertujuan untuk mendeksripsikan nilai nilai Pendidikan } \\
\text { dalam tradisi tingkeban budaya masyarakat suku Jawa dari perspektif } \\
\text { filosofis. Motode pada penelitian ini adalah metode kualitatif dengan } \\
\text { pendekatan deskriptif. Peneliti dalam mengumpulkan data primer dari } \\
\text { hasil observasi dan wawancara serta data sekunder dari kajian pustaka. } \\
\text { Dalam mencapai hasil penelitian tersebut, peneliti menggunakan kajian } \\
\text { filsafat seperti epsitemology, aksiology dan kosmology. Kemudian dari } \\
\text { beberapa pertanyaan yang dimunculkan akan dianalisis untuk } \\
\text { mendeskripsikan atau menggambarkan sebuah objek yang berhubungan } \\
\text { dengan penelitian serta bertujuan untuk mencari dan menemukan proses } \\
\text { dan nilai - nilai pendidikan yang ada dalam tradisi tingkeban budaya } \\
\text { masyarakat suku Jawa. Dalam penelitian ini disimpulkan bahwa nilai - } \\
\text { nilai Pendidikan dalam tradisi tingkeban budaya masyarakat suku Jawa } \\
\text { adalah nilai religi, nilai sosial, nilai ekonomi, dan nilai estetika. }\end{array}$ \\
\cline { 2 - 3 } Kata Kunci & Nilai, Filosofis, Suku Jawa, Tingkeban \\
Keywords & (2021). Jurnal Ability, 2(4).
\end{tabular}

\section{PENDAHULUAN}

Indonesia terkenal sebagai bangsa yang memiliki budaya majemuk (pluralistic) (Supartono, 2001). Indonesia juga disebut dengan Negara budaya karena di Indonesia kaya akan berbagai budaya-budaya yang beranekaragam. Salah satu kebudayaan yang terdapat di Indonesia adalah budaya pada masyarakat suku Jawa. Suku jawa merupakan bangsa terbesar di Jawa Tengah, Jawa Timur, Daerah Istimewa Yogyakarta, Kabupaten Indramayu dan masih banyak lainnya. Mayoritas orang suku Jawa adalah umat Islam, dengan beberapa minoritas yaitu Kristen, Kejawen, Hindu, Buddha, dan Khonghucu. Meskipun demikian, peradaban orang suku Jawa telah dipengaruhi oleh lebih dari seribu tahun interaksi antara budaya Kejawen dan Hindu-Buddha, dan pengaruh ini masih terlihat dalam sejarah, budaya, tradisi, dan bentuk kesenian Jawa. Dengan populasi global yang cukup besar, suku Jawa ialah kelompok etnis terbesar keempat di antara umat Islam di seluruh dunia, setelah bangsa Arab, suku Bengali dan suku Punjab. 
Ability : Journal of Education and Social Analysis

Volume 2, Issue 4, Oktober 2021

Page : $77-88$

Masyarakat suku Jawa adalah kesatuan hidup orang-orang Jawa yang berinteraksi menurut suatu sistem adat-istiadat sistem norma, dan sistem budaya Jawa yang bersifat kontinyu, dan yang terikat oleh suatu rasa identitas bersama yaitu orang Jawa (Siswanto, 2009). Masyarakat suku Jawa mempunyai beragam budaya dan tradisi yang merupakan warisan nenek moyang. Tradisi itu sendiri dilakukan sebagai suatu perencanaan, tindakan, dan perbuatan yang sudah menjadi tata nilai luhur. Tata nilai luhur tersebut sudah menjadi warisan secara turun-temurun. Nilai luhur tersebut dilakukan oleh masyarakat suku Jawa sebagai bentuk kehati-hatian dalam melaksanakan pekerjaan agar dapat selamat secara lahir dan batin. Berbagai macam upacara adat pada masyarakat suku Jawa dilakukan sejak sebelum manusia lahir sampai meninggal dunia. Salah satu budaya dan tradisi tersebut adalah upacara tingkeban. Tradisi tingkeban dilakukan pada saat usia kehamilah tujuh bulan.

Istilah tingkeban juga disebut dengan mitoni berasal dari kata pitu (tujuh). “Tujuh dalam Bahasa Jawa adalah pitu, maka jadilah mitoni” (Sholikin, 2010:). "Upacara adat Jawa ini dilakukan ketika calon ibu mengandung bayi pertama di usia tujuh bulan" (Bayuadhy, 2015). Menurut Bratawidjaja (1988) "Upacara tingkeban adalah salah satu tradisi masyarakat jawa". Hakikat dari tingkeban adalah mendoakan calon bayi dan calon ibu yang mengandung agar selamat sampai saat kelahirannya nanti (Bayuadhy, 2015). Berdasarkan pendapat di atas dapat disimpulkan, budaya tingkeban merupakan tradisi yang sudah dilakukan sejak jaman nenek moyang secara turun menurun untuk melindungi bayi yang masih dalam kandungan yang berusia tujuh bulan pada kehamilan pertama calon ibu. Tradisi ini bertujuan untuk mendoakan agar bayi yang dikandung ibu sehat dan selamat. serta kelak bisa lahir secara normal dan ibu juga dapat melahirkan dengan selamat.

Setelah mengetahui pengertian dari tingkeban, disini peneliti ingin mengetahui tentang nilai - nilai yang terdapat dalam tradisi tingkeban pada masyarakat suku Jawa dalam presfektif filosofis. Nilai adalah sesuatu yang berguna, berharga, indah, yang dapat memperkaya harkat dan martabat manusia (Syarbaini, 2014). Dan nilai menurut Allport (Syarbaini, 2014) meliputi nilai ekonomi, nilai religius, nilai teori, nilai sosial, nilai estetika, dan nilai politik. Namun, nilai-nilai yang digunakan dalam penelitian ini adalah nilai religius, nilai sosial, nilai ekonomi dan nilai estetika yang terdapat dalam tradisi tingkeban pada masyarakat suku Jawa.

Pada penelitian ini, tradisi tingkeban akan ditinjau dari perspektif filosofis. Untuk mencapai hasil penelitian, maka akan diajukan beberapa pertanyaan filosofis terkait tradisi tingkeban dalam budaya masyarakat suku jawa. Perspektif filosofis adalah suatu cara pandang berdasarkan mempertanyakan 
Ability : Journal of Education and Social Analysis

Volume 2, Issue 4, Oktober 2021

Page : $77-88$

segala sesuatu (Kebung, 2011). Sehingga perspektif filosofis akan selalau berawal dari pertanyaan dan berakhir juga dengan pertanyaan. Dengan demikian berpikir sebagai suatu sistem berpikir terbuka terhadap segala hal termasuk dalam hal kebudayaan.

Berdasarkan pemaparan diatas, terdapat beberapa pertanyaan filosofis yang diajukan untuk mendeskripsikan nilai-nilai pendidikan yang terdapat dalam tradisi tingkeban budaya mayarakat suku Jawa, yaitu : Bagaimana pemahaman masyarakat suku Jawa terhadap tradisi tingkeban? bagaimana dimensi filosofis tradisi tingkeban budaya masyarakat suku jawa ? Apa nilai nilai Pendidikan yang terdapat pada tradisi tingkeban budaya masyarakat suku Jawa ? Berdasarkan penjelasan tersebut maka peneliti akan membahasnya dalam penelitian ini yang berjudul Nilai-Nilai Pendidikan dalam Tradisi Tingkeban Budaya Masyarakat Suku Jawa Ditinjau Dari Perspektif Filosofis

Selanjutnya dengan adanya penelitian ini diharapkan dapat bermanfaat secara teoritis maupun praktis. Secara teoritis diharapkan dapat memberikan pengetahuan dan pemahaman mengenai nilai-nilai pendidikan yang terdapat dalam tradisi tingkeban yang masih dilaksanakan oleh masyarakat suku Jawa. Sedangkan secara praktis khususnya masyarakat suku Jawa penelitian ini diharapkan dapat memberikan masukan kepada masyarakat suku jawa agar tradisi tingkeban dapat terus dilestarikan karena sudah menjadi tradisi turun temurun. Untuk peneliti sendiri diharapkan hasil penelitian ini dapat menambah wawasan dan pengetahuan peneliti mengenai nilai-nilai yang terdapat dalam tradisi tingkeban pada masyarakat suku jawa.

\section{METODE PENELITIAN}

Metode penelitian yang digunakan dalam penelitian ini adalah penelitian deskriptif. Metode penelitian deskriptif adalah suatu metode untuk meneliti status suatu kelompok manusia, suatu objek, suatu kondisi, suatu sistem pemikiran, ataupun suatu peristiwa pada masa sekarang (Nazir, 2014). Pendekatan yang digunakan dalam penelitian ini adalah pendekatan kualitatif. Sama halnya dengan pendapat Moleong (2012) bahwa penelitian kualitatif adalah penelitian yang bermaksud untuk memahami fenomena tentang apa yang dialami oleh subjek penelitian misalnya prilaku, persepsi, motivasi, tindakan dan lain-lain. Secara holistik dan dengan cara deskripsi dalam bentuk kata-kata dan bahasa pada suatu konteks khusus yang alamiah dan dengan memanfaatkan berbagai metode alamiah. Metode pengumpulan data pada penelitian deskriptif kualitatif ini akan didukung dengan data primer dari hasil wawancara dan obervasi peneliti di lapangan serta data sekunder dari hasil 
Ability : Journal of Education and Social Analysis

Volume 2, Issue 4, Oktober 2021

Page : $77-88$

kajian pustaka beberapa artikel-artikel ilmiah yang bekaitan dengan budaya dan kajian filosofis Mirzaqon dalam (Three Rahmadona, 2020).

Seluruh data dan informasi yang diperoleh, selanjutnya dianalisis dengan pola kualitatif dan diinterpretasikan secara utuh mulai dari awal penelitian sampai penelitian berakhir. Kemudian yang menjadi indikator dalam penelitian ini adalah nilai - nilai dari Alport (Syarbaini, 2014) yang terdiri dari nilai teori, nilai ekonomi, nilai estetika, nilai sosial, nilai politik, dan nilai religi. Tetapi, nilai yang akan digunakan dalam penelitian ini hanya empat saja yaitu nilai religi, nilai sosial, nilai ekonomi, dan nilai estetika. Sehingga keempat nilai-nilai inilah yang akan dijadikan indikator dalam tradisi tingkeban pada masyarakat suku Jawa.

\section{HASIL DAN PEMBAHASAN}

\section{Pemahaman Tradisi "Tingkeban" Dalam Budaya Masayarakat Suku Jawa}

Tingkeban merupakan tradisi lama yang diwariskan dari generasi ke generasi. Tradisi ini telah berkembang sejak zaman dahulu, pada waktu Pemerintahan Prabu Jayabaya. Menurut cerita, ada seorang wanita bernama Niken Satingkeb yang menikah dengan seorang punggawa Kerajaan Kediri bernama Sadiyo. Dari perkawinan itu lahir sembilan anak, sayangnya tidak ada seorang pun bertahan hidup. Namun demikian, hal itu tidak membuat Sadiyo dan Niken merasa putus asa, malahan mereka terus berusaha untuk mendapatkan keturunan. Akhirnya, mereka berdua pergi menghadap Raja Jayabaya untuk mengadukan nasibnya dan mohon petunjuk agar mereka dianugerahi anak lagi yang tidak mengalami nasib seperti anak-anaknya terdahulu.

Selanjutnya, Jayabaya, raja yang arif dan bijaksana itu merasa terharu ketika mendengar pengaduan Niken Satingkeb dan suaminya. Dia memberi petunjuk kepada Setingkeb untuk menjalani tiga hal. Pertama, mandi setiap hari tumbak (Rabu). Kedua, mandi setiap hari budha (Sabtu). Dan ketiga mandi Suci, dilakukan pada pukul 17.00, dengan memanfaatkan air suci dan gayung yang terbuat dari tempurung kelapa (bathok) dan disertai do'a atau mantera. Setelah mandi Nyai Niken harus memakai pakaian serba putih, berikut dua buah kelapa gading yang diletakkan atau ditempelkan pada perut. Kelapa gading mempunyai makna simbolik, yaitu Sang Hyang Wisnu dan Dewi Sri atau Arjuna dan Sumbadra. Artinya, anak yang akan dilahirkan kelak diharapkan memiliki paras yang tampan atau cantik, setampan Arjuna bila bayi terlahir laki laki, dan secantik Subadra jika ia berjenis perempuan.

Tradisi tingkeban merupakan upacara yang dilakukan ketika usia kehamilan seorang ibu menginjak tujuh bulan. Dalam upacara ini sang ibu 
Ability : Journal of Education and Social Analysis

Volume 2, Issue 4, Oktober 2021

Page : $77-88$

yang sedang hamil dimandikan dengan air setaman dan disertai dengan do'a yang bertujuan untuk memohon kepada Tuhan Yang Maha Esa agar selalu diberikan rahmat dan berkah sehingga bayi yang akan dilahirkan selamat dan sehat. Tingkeban biasanya dilakukan saat kandungan berumur tujuh bulan. Dalam tradisi masyarakat Jawa seorang wanita yang baru hamil harus melakukan beberapa upacara selamatan. Tradisi ini dilakukan agar bayi yang dikandung dapat lahir dengan lancar, selamat serta tidak kurang suatu apapun, dan akhirnya, ia akan mendapat kebahagiaan hidup di kemudian hari.

Dengan diadakan tradisi tingkeban ini masyarakat suku jawa sangat antusias saling membantu khususnya keluarga dan para tetangga terdekat dalam prosesi tersebut. Dengan melaksanakan tradisi ini maka dapat mempererat tali persaudaraan dan juga sebagai ajang silaturahmi antar anggota keluarga dan tetangga terdekat.

\section{Dimensi Filosofis Tradisi "Tingkeban" Dalam Budaya Masyarakat Suku Jawa}

Kebudayaan menurut Taylor adalah totalitas yang kompleks yang mencakup pengetahuan, kepercayaan, seni, hukum, moral, adat, dan kemampuan - kemampuan serta kebiasaan - kebiasaan yang diperoleh sebagai anggota masyarakat (Imran Manan,1989)

Orang Jawa mempunyai tradisi pemikiran yang unik, bersifat metafisik dan lekat dengan mistikisme atau mistisisme (menurut istilah Mulder, 1984; Laksono, 1985; Anderson, 1986; Geertz, 1989; Mulder, 2001). Tradisi pemikiran ini diaplikasikan dalam segala aspek budaya, baik yang bersifat material ataupun non-material. Kebudayaan tersebut mewujudkan lewat upacara ritual mulai tradisi sebelum kelahiran sampai upacara pasca kematian, mulai dari bentuk arsitektur sampai cara berpikir masyarakatnya.

Cara berpikir masyarakat suku Jawa sangat lekat dengan mistikisme. Hal ini tampak ketika ada seorang wanita/calon ibu sedang hamil dengan rela melakukan apapun demi menjaga kehamilan tersebut agar senantiasa sehat, aman dan nyaman. Demi menjaga kehamilan tidak hanya dilakukan dengan menjaga kesehatan dan keamanan kandungan, tetapi juga menghindari segala hal yang menjadi larangan bagi wanita hamil. Selain istri yang menghindari segala larangan ini, sang suami pun tak ketinggalan untuk ikut menghindarinya.

Berikut adalah beberapa larangan bagi wanita hamil

- Pertama, Wanita hamil dilarang duduk di tengah pintu rumah karena menurut mitos Jawa, duduk di tengah pintu ini akan membuat proses kelahiran susah serta menyakitkan. 
Ability : Journal of Education and Social Analysis

Volume 2, Issue 4, Oktober 2021

Page : $77-88$

- Kedua, Menurut adat Jawa, wanita hamil dilarang merendam pakaian kotor terlalu lama. Ini dipercaya bisa membuat kaki ibu hamil bengkak dan terasa berat.

- Ketiga, Tidak diperkenankan bagi ibu hamil untuk membunuh segala macam hewan. Suami wanita ini juga dilarang membunuh hewan karena dipercaya bisa membuat janin di kandungan cacat atau bahkan gugur.

- Keempat, Wanita hamil dilarang bergumam atau "mbhatin" tentang sesuatu hal yang dirasa cukup aneh. Ini dipercaya akan membuat bayi yang dikandung mengalami hal serupa dengan apa yang digumamkan ibunya.

- Kelima, Ibu hamil dilarang menggaruk perut atau bokong yang gatal karena ini dipercaya bisa membuat kulit bayi di dalam kandungan lebam.

- Keenam, Suami wanita yang sedang hamil dilarang memancing atau pun berburu hewan apapun itu. Menurut mitos Jawa, suami yang memancing atau berburu bisa menyebabkan bayi di dalam kandungan cacat atau sumbing.

- Ketujuh, Menurut adat Jawa, wanita yang sedang hamil dilarang menjahit kain dengan jarum secara manual. Orang tua zaman dulu percaya jika aktivitas menjahit bisa menyebabkan bayi lahir cacat.

- Kedelapan, Wanita yang sedang hamil dilarang membakar peralatan bayi atau peralatan untuk membersihkan tubuh seperti bungkus sabun, tisu dan sejenisnya. Orang tua zaman dulu percaya jika membakar bendabenda ini bisa membuat kulit bayi ruam bahkan seperti terbakar.

Tindakan ini merupakan Tindakan tradisional mengikuti kebiasaan kebiasaan orang terdahulu. Meskipun tidak mengetahui hubungan nalar dengan tindakan yang dilakukan, sedangkan pola pikir percaya atau tidak percaya merupakan cara berfikir masyarakat yang tidak mempercayai mistikisme. Menurut Purwadi (2005: 134-135), dalam menyelenggarakan tradisi harus menurut peraturan adat yang berlaku, yaitu pada Hari Selasa atau Sabtu dan jatuh pada tanggal ganjil. Seyogyanya tanggal tujuh menurut kalender Jawa. Pemilihan tanggal ganjil itu, melambangkan umur kehamilan (tujuh bulan) yang hitungannya adalah ganjil. Dilaksanakan pada siang hari, biasanya mulai jam 11 siang, karena menurut tradisi masyarakat suku Jawa, pada saat itulah para bidadari turun dari kayangan untuk mandi.

Adapun Pelaksanaan ritual siraman dilakukan dengan beberapa tahap.

- Pertama, Siraman dilakukan oleh para sesepuh, berjumlah tujuh orang, antara lain bapak, anak yang sedang hamil, nenek, bude, atau yang 
dipandang lebih tua dalam keluarga. Siraman pertama pada upacara orang hamil dengan mandi dilaksanakan oleh ayah dari sang calon ibu, lalu dilanjutkan oleh ibu dari sang calon ibu, kemudian, dilanjutkan oleh ibu para sesepuh.

- Kedua, Setelah ketujuh sesepuh selesai menyirami si calon ibu, acara dilanjutkan dengan pemakaian dua setengah meter kain putih yang dililitkan ke tubuh ibu calon bayi. Selanjutnya, upacara memasukkan telur ayam kampung kedalam kain calon ibu oleh sang suami melewati perut hingga pecah. Hal ini dilaksanakan dengan harapan bahwa ibu calon bayi tersebut dapat melahirkan dengan lancar dan lahir dengan mudah tanpa arah melintang.

- Ketiga, Selesai memasukkan telur yang melewati perut sang calon ibu, acara dilanjutkan dengan berganti kain panjang dan pakaian sebanyak tujuh kali. Dalam acara berganti pakaian ini dilandasi dengan kain putih. Kain putih bermakna bahwa bayi yang dilahirkan adalah suci, putih dan bersih.

- Keempat, Pada acara berganti pakaian sebanyak tujuh kali dipersiapkan kebaya tujuh macam, kain panjang batik atau jarik tujuh macam, dua meter lawe, dan stagen. Salah satu dari jarik yang dipakai untuk berganti ada yang bercorak Truntum.

- Kelima, Memasukkan dua kelapa gading di dekat perut ibu yang hamil. Kelapa itu diperosotkan dari atas kebawah dan diterima oleh calon nenek. Makna dari acara tersebut adalah agar bayinya lahir dengan lancar dan mudah. Kemudian, diteruskan dengan acara calon nenek dari pihak calon ibu menggendong kelapa gading yang telah digambari tokoh Kamajaya dan Dewi Kamaratih bersama ibu besan.

- Keenam, Calon ayah memiliki satu di antara dua buah kelapa gading yang bergambar tokoh Kamajaya dan Dewi Kamaratih. Pada waktu memilih satu di antara buah kelapa gading, kedua kelapa tersebut berada dalam posisi terbalik. Hal ini dimaksudkan agar calon ayah tidak bisa melihat gambar tokoh Kamajaya atau Kamaratih. Selanjutnya, kelapa yang sudah dipilih itu dipecah atau dibelah. Apabila kelapa yang dipilih bergambar tokoh Kamajaya, diharapkan bayi yang lahir adalah laki-laki tampan seperti Kamajaya. Apabila kelapa yang dipilih bergambar tokoh Dewi Kamaratih, diharapkan bayi yang lahir adalah perempuan yang cantik rupawan seperti halnya Dewi Kamaratih.

- Ketujuh, Memilih nasi kuning yang terletak di dalam takir sang suami. Setelah itu, dilanjutkan dengan acara jual dawet dan rujak. Bagi pembeli yang menginginkan dawet atau rujak cukup membayar dengan pecah 
genting. Uang hasil penjualan, lalu dimasukkan kedalam kuali yang terbuat dari tanah liat. Kuali yang berisi uang yang terbuat dari pecahan genting itu, lalu dibawa kedeket pintu dan dipecah di depan pintu tersebut. Makna dari upacara pecah kuali tersebut adalah diharapkan agar kelak anaknya mendapatkan anugrah yang berlimpah dan selalu ikhlas beramal.

\section{Nilai-Nilai Pendidikan Yang Terkandung Dalam Tradisi "Tingkeban" Budaya Masyarakat Suku Jawa}

\section{Nilai Religi}

Tradisi tingkeban memberikan dasar pengenalan tauhid (keesaan Allah) pada anak dalam kandungan. Artinya tradisi ini pada dasarnya adalah permohonan kepada Allah, Tuhan semesta alam untuk memberi keselamatan dan kebaikan bagi ibu dan calon bayi. Sang Ibu memberikan keyakinan dan pemahaman bahwa Allahlah yang berkuasa atas keselamatan dan kebaikan setiap hamba-Nya. sejatinya sejak dalam kandungan sang Ibu memberikan Pendidikan pengenalan aqidah sejak dini, ruh anak tersebut telah berikrar untuk beriman kepada Allah. Nilai yang didapatkan dari tradisi ini adalah agar orang tua atau suami dan istri yang sedang mengandung senantiasa selalu mendekatkan diri kepada Allah SWT, serta berdo'a demi kesehatan dan keselamatan ibu dan anak.

\section{Nilai Sosial}

Tradisi tingkeban ini memiliki nilai sosial dimana dalam pelaksanaan tradisi ini para tetangga dan saudara datang dan membantu meringankan pekerjaan dari tuan rumah yang harus memasak makanan, kemudian ikut membantu menyiapkan makanan untuk selamatan dan membantu mencari bahan - bahan yang digunakan untuk tingkeban. Kemudian mengundang para tamu yang terdiri dari kerabat dan tetangga sanak saudara untuk datang menghadiri selamatan dan do'a bersama, hal ini terdapat nilai-nilai saling menghargai. Setelah acara selamatan selesai sebagai ucapan terimaksih tuan rumah kepada para tamu yang sudah datang untuk mendo'akan calon ibu dan bayi dengan memberikan makanan dan lauk pauknya. Tujuan dari hal ini adalah untuk memperkuat silahturahmi dan tali persaudaraan antara para tetangga dan saudara.

\section{Nilai Ekonomi}

Dalam pelaksanaan tradisi tingkeban terdapat nilai ekonomi disini, misalnya pada saat saudara dan tetangga memberikan sumbangan kepada tuan rumah yang berupa beras ataupun makanan lainnya, 
nantinya apabila saudara dan tetangga tersebut mempunyai acara selamatan akan dibantu juga oleh tuan rumah. Kemudian ada juga dari beberapa saudara yang memberikan buah-buahan yang digunakan dalam tradisi tingkeban secara cuma-cuma tanpa mengharapkan untuk dikembalikan lagi. Tetangga juga membantu atau memberikan sumbangan kepada tuan rumah pada saat tradisi tingkeban mereka membawa dalam bentuk beras atau sesuai dengan kemampuan masingmasing. Kemudian pemberian bingkisan kepada para tamu yang datang sebagai ucapan terimakasih karena telah melakukan do'a bersama, memberikan makanan kepada para saudara dan tetangga yang telah datang membantu. Dalam hal ini terdapat nilai ekonomi yang tidak bisa disebutkan nominalnya, namun nilai ekonomi tersebut bersifat membantu pemilik rumah.

\section{Nilai Estetika}

Nilai estetika adalah rasa keindahan yang di dalamnya terdapat cinta kasih maupun kasih sayang karena adanya kecintaan yang dirasakan oleh manusia. Pada nilai ini terlihat dalam acara memecah kelapa gading, dimana kelapa tersebut digambari dengan Kamanjaya dan ratih atau Harjuna dan Wara Subrada atau Srikandi. Kedua kelapa tersebut diletakan dalam posisi terbalik agar calon ayah tidak dapat melihat gambar tersebut. Apabila gambar kelapa gading yang dipecahkan ayah bergambar Kamajaya atau Harjuna, maka bayi akan dilahirkan laki-laki, apabila kelapa yang dipecahkan bergambar Ratih atau Srikandi, maka bayi yang akan dilahirkan adalah perempuan.

Berdasarkan nilai-nilai Pendidikan yang terdapat dalam tradisi tingkeban di atas, didapatkan juga nilai negatif yang terdapat di nilai ekonomi yaitu pada saat tuan rumah harus mempersiapkan biaya untuk tradisi tingkeban yaitu membeli bahan - bahan yang dibutukan untuk tradisi tersebut, karena biaya yang dibutuhkan tidak sedikit. Kemudian memberikan bingkisan atau nasi beserta lauk pauknya kepada para tetangga dan saudara yang datang sebagai ucapan terimakasih telah membantu. Namun, selama tradisi tersebut tidak menyimpang dari hukum agama dan lebih banyak nilai positive dibandingkan dengan nilai negative maka nilai tersebut akan tetap dipertahankan dan dilaksanakan karena sudah menjadi kebiasaan masyarakat sejak lama serta sudah menjadi tradisi yang dilakukan secara turun-temurun. Hal tersebut sejalan dengan pendapat dari Sztompka (2014:70) bahwa "Tradisi merupakan segala sesuatu yang disalurkan dari masa lalu ke masa kini". Budaya daerah atau tradisi memegang peranan penting bagi kelangsungan kebudayaan nasional. 
Oleh karena itu, tradisi sudah seharusnya dipelihara dan dijaga dalam kehidupan masyarakat Indonesia. Salah satunya dengan mengangkat budaya daerah dan mempelajari secara mendalam, sehingga keberadaan kebudayaan atau budaya daerah tersebut dapat dikenali dan diteruskan oleh generasi penerus bangsa serta menerapkan nilai-nilai yang terkandung dalam budaya tersebut dalam berbagai aspek kehidupan. Salah satu bentuk dari kebudayaan yang berkembang di masyarakat adalah tradisi-tradisi (Utami, 2016). Pada masyarakat yang kental budayanya akan terus melakukan suatu tradisi-tradisi yang dianggap sebagai hal yang memberi manfaat dan kesejahteraan bagi masyarakat itu sendiri dan sebagai warisan dari leluhurnya. Oleh karena itu, masyarakat akan tetap mempertahankan tradisi tersebut. "Masyarakat pada dasarnya tidak dapat dilepaskan dari nilai-nilai tradisi dan budaya yang turun dari generasi satu ke generasi seterusnya" (Basyari, 2014).

\section{KESIMPULAN}

Tingkeban merupakan tradisi yang sudah dilakukan sejak jaman nenek moyang secara turun menurun untuk melindungi bayi yang masih dalam kandungan yang berusia tujuh bulan pada kehamilan pertama calon ibu. Tradisi ini bertujuan untuk mendoakan agar bayi yang dikandung ibu sehat dan selamat. serta kelak bisa lahir secara normal dan ibu juga dapat melahirkan dengan selamat. tradisi tingkeban pada suku jawa mempunyai nilai-nilai Pendidikan dan menjadi ciri khas dari masyarakat suku jawa yaitu meliputi nilai religi, nilai sosial, nilai ekonomi dan nilai estetika yang terdapat dalam tradisi tingkeban pada masyarakat suku Jawa.

\section{REFERENCES}

Analisis Nilai-Nilai Dalam Tradisi Tingkeban Pada Masyarakat Jawa Di Desa Cendana Kecamatan Muara Sugihan Kabupaten Banyuasin Khaerani, Alfiandra, Emil El Faisal

Anderson, Benedict. 1986. "Gagasan tentang Kekuasaan dalam Budaya Jawa" dalam buku Miriam Budiardjo. Aneka Pemikiran tentang Kuasa dan Wibawa. Jakarta: Penerbit Sinar Harapan.

Basyari, Iin. W. (2014). Nilai-Nilai Kearifan Lokal (Lokal Wisdom) Tradisi Memitu pada Mayarakat Cirebon (Studi masyarakat Desa Setupatok Kecamatan Mundu). Edunomic.2(1):1-55.http://id. portalgaruda.org $/$ ?ref=search\&mod=document\&select $=$ title\& $\mathrm{q}=$ tradisi $+\mathrm{ti}$ ngkeban\&button=Search+Docum ent.

Bayuadhy, Gesta. (2015). Tradisi-tradisi Adiluhung Para Leluhur Jawa. Yogyakarta: Dipta. 
Ability : Journal of Education and Social Analysis

Volume 2, Issue 4, Oktober 2021

Page : 77-88

Bratawidjaja, Thomas. W. (1988). Upacara Tradisional Masyarakat Jawa. Jakarta: Pustaka Sinar Harapan.

Edueksos.5(1):99111.http:/ / download.portalgaruda.org/article.php?article=13 $5889 \& \mathrm{val}=5651$

Iswah Adriana, (2012) “Neloni, Mitoni Atau Tingkeban:(Perpaduan antara Tradisi Jawa dan Ritualitas Masyarakat Muslim)," KARSA: Jurnal Sosial dan Budaya Keislaman 19, no. 2 (2012).

Ign Gatut Saksono, (2012) Djoko Dwiyanto;, Faham Keselamatan dalam Budaya Jawa Ampera Utama.

https://id.wikipedia.org/wiki/Suku_Jawa

https://www.fimela.com/parenting/read/3812253/8-mitos-larangan-bagi-

wanita-hamil-menurut-adat-jawa

https://dosensosiologi.com/nilai-estetika/

Jurnal : Analisis Nilai-Nilai Dalam Tradisi Tingkeban Pada Masyarakat Jawa Di

Desa Cendana Kecamatan Muara Sugihan Kabupaten Banyuasin Khaerani, Alfiandra, Emil El Faisal

Kangjeng Pangeran Harya Tjakraningrat, Kitab primbon betaljemur ada makna/Kanjeng Pangeran Harya Cakraningrat, Serie Adamakna (Yogyakarta: Soemodidjojo Mahadewa, 1994)

Kebung, Konrad (2011). Filsafat Ilmu Pengetahuan. Jakarta : Prestasi Pustaka Publisher.

Lexy J. Moleong (2002). Metodologi Penelitian Kualitatif, Bandung: Remaja Rosdakarya

Made Pidarta,2013 “Landasan Kependidikan” Jakarta :Rineka Cipta

Nazir, (2014). Metode Penelitian. Bogor: Ghalia Indonesia.

Purwadi, (2005). Upacara Tradisional Jawa -Menggali Untaian Kearifan Lokal. Yogyakarta: Pustaka Pelajar.

Sholikhin, Muhammad. (2010). Ritual \&Tradisi Islam Jawa. Yogyakarta: Narasi) Susanti, (2015) Jurnal,Inayatul Ulya "Nilai Pendidikan dalam Tradisi Mitoni" Syarbaini, Syahrial. (2014). Pendidikan Pancasila. Bogor: Ghalia Indonesia)

Supartono Widyosiswoyo, Ilmu Budaya Dasar (Bogor Selatan : Ghalia Indonesia, 2001)

Sztompka, Piotr. (2014). Sosiologi Perubahan Sosial. Jakarta: Prenada.

Three Rahmadona1 \& Nelly Astimar. (2020). Implementasi Pendekatan Saintifik dalam Pembelajaran Tematik Terpadu Di Sekolah Dasar (Studi Literatur). Jurnal Pendidikan Tambusai 1939 Volume 4 Nomor 3 Tahun 2020 Halaman 1939-1949 SSN: 2614-6754 (print) ISSN: 2614-3097(online)

Utami, dkk. (2016). Peran Tradisi Seren Taun dalam Upaya Meningkatkan Pewarisan Nilai-Nilai Sosial dan Budaya di Kalangan Remaja Kelurahan 
Ability : Journal of Education and Social Analysis

Volume 2, Issue 4, Oktober 2021

Page : $77-88$

Cigugur Kecamatan Cigugur Kabupaten Kuningan. Edueksos. 5(1): 99111. http://download.portalgaruda.org/artic le.php?article $=135889 \& \mathrm{val}=5651$

Yohanes Boanergi "Pergeseran adat mitoni": Persinggungan Antara Budaya Dan Agama" 